\title{
Sublittoral and profundal chironomid (Diptera) communities of Lake Vico (Central Italy) : relationship to the trophic level
}
M. Seminaral
M. Bazzanti1
C. Tamorri

Keywords : Chironomidae, community structure, depth distribution, trophic level, lake, Italy.

Sublittoral and profundal chironomid community structure, depth distribution and relationship to the trophic level of the waters were investigated in Lake Vico (Central Italy) during 1985-1986. PCA analysis indicated a depth-dependent group of true profundal stations at 20,30 and $40 \mathrm{~m}$ depths, characterized by Micropsectra, Procladius, Microtendipes, Tanytarsus and Paratendipes, and a group of $10 \mathrm{~m}$ stations, characterized by Cryptochironomus, Polypedilum bicrenatum gr., Cladopelma lateralis gr. and C. laccophila gr., representing the sublittoral features of this depth. In agreement with the chemical data, the chironomid community indicated a mesotrophic condition of Lake Vico, with a tendency towards an increasing trophic level in the deepest zone. A significant role in revealing future trophic changes in the lake may be attributed to the key-indicator Micropsectra.

Communautés de Chironomidés (Diptera) des zones sublittorale et profonde du Lac Vico (Italie Centrale) : relation avec le niveau trophique.

Mots clès : Chironomidés, structure des communautés, distribution selon la profondeur, niveau trophique, lac, Italie.

La structure des communautés sublittorale et profonde des Chironomidés, leur distribution selon la profondeur et leur relation avec le niveau de trophie du Lac Vico ont été étudiées au cours des années 1985-1986. L'Analyse en Composantes Principales permet de différencier un groupement des stations profondes à $-20,-30$ et $-40 \mathrm{~m}$ d'un groupement des stations de la zone sublittorale à - $10 \mathrm{~m}$. Le premier groupement est caractérisé par les genres Microspsectra, Procladius, Microtendipes, Tanytarsus et Paratendipes et le deuxième par les genres Cryptochironomus, Polypedilum bicrenatum gr., Cladopelma lateralis gr. et $C$. laccophila gr. Corrélativement aux données chimiques, la communauté chironomidienne correspond bien à l'état mésotrophique du lac avec une tendance à l'augmentation de la trophie dans la zone profonde. Le rôle significatif du genre Micropsectra dans la détection de futurs changements trophiques du lac est souligné.

\section{Introduction}

The family Chironomidae constitutes a widespread, diverse and abundant group of invertebrates inhabiting all freshwater ecosystems. Their community structure has traditionally been investigated, and many workers underlined their relevant role both in lake metabolism and water quality assessment (Warwick 1975, Gallepp et al. 1978, Granéli 1979, Saether 1979, Wiederholm 1980, Gardner et al. 1983, Wasson 1984, Seminara \& Bazzanti 1988).

1. Dipartimento di Biologia Animale e dell'Uomo, Universicà « La Sapienza », v. le dell'Universita 32, 00185 Roma, Italia.
In European countries some topics involving chironomids, e.g. community structure, composition, phenology and seasonal variations, have been long and extensively studied, while other aspects, e.g. depth distribution, are reported less frequently in literature (Laville 1971, Aagaard 1978, Lindegaard 1980, Kansanen et al. 1984, Gerstmeier 1989 a, Heinis 1989 , Heinis et al. in press).

This paper deals with the sublittoral and profundal chironomid communities of Lake Vico (Central Italy) in order to examine their structure, their depth distribution, and their relationships with the trophic status of the lake. The results of this paper also contribute to the knowledge of this dipteran family in 
Central Italian lakes (Nocentini 1973, Bazzanti 1981, Bazzanti \& Loret 1982, Mastrantuono 1986, Bazzanti \& Seminara 1987 a \& b, Mastrantuono 1987, Mastrantuono \& La Rocca 1988, Seminara \& Bazzanti 1988). This study forms part of a wider research (P.I.M. ; Piano Integrato Mediterraneo) aimed at assessing the lake water quality and at an adequate strategy to improve local fish management. Data about the whole profundal benthic community of the lake will be published elsewhere.

\section{Study area and methods}

Lake Vico (Fig. 1) is a volcanic water body surrounded by both agricultural and non-anthropized lands. It is situated about $50 \mathrm{~km}$ North of Rome in the volcanic area of the Cimini Mountains, where a Regional Nature Reserve including the lake and the neighbouring area was instituted in 1982. The lake has a catchment area of $28.05 \mathrm{~km}^{2}$ and a theoretical water renewal time of about 17 years (Barbanti 1969). Specific morphometric data are reported in figure 1. Commercial fish stock (mainly coregonids) is managed by means of artificial reproduction of the autochthonous breeding individuals. Moreover, the lake waters are utilized for sportfishing and recreational purposes. In the surrounding grounds a massive use of fertilizers and pesticides for agricultural practices was recorded over the last two decades. Lake Vico was first studied by the Hydrobiological Institute of Pallanza during 1969-1970 (Barbanti et al. 1971). The results, based on both physico-chemical and biological data, indicated a mesotrophic condition of the waters. In 1985-1986, a similar content of nutrients but a higher orthophosphate concentration and a more pronounced summer-autumn deoxygenation in the deepest layers of the hypolimnion were observed (Table I). During the study, $\mathrm{pH}$ ranged from 7.1 to 8.7 , temperature from 6.2 to $25^{\circ} \mathrm{C}$ and transparency from 3.5 to $12.6 \mathrm{~m}$.

Benthic samples were collected bimonthly from May 1985 to March 1986 in three sites of the lake (Fig. 1). Sampling depths were established at 10, 20, 30 and $40 \mathrm{~m}$ at site $\mathrm{A}$, and at 10 and $20 \mathrm{~m}$ at sites $B$ and $C$. At each depth and date triplicate samples were obtained by an Ekman grab (area : $225 \mathrm{~cm}^{2}$ ), for a total of 144 samples during the study. Material was filtered through a $0.28 \mathrm{~mm}$ mesh screen and preserved in $10 \%$ formalin. Chironomid larvae and pupae were hand-sorted, counted, weighed and then
Table I. Selected chemical parameters monthly registered from May 1985 to March 1986 in the waters of Lake Vico (Nicotra, 1987).

\begin{tabular}{|c|c|c|c|c|c|c|}
\hline Depth $(m)$ & & 0 & 10 & 20 & 30 & 40 \\
\hline \multirow{3}{*}{ Oxygen (mg/) } & $\min$. & 8.2 & 9.0 & 4.2 & 1.0 & 0.2 \\
\hline & mean & 9.4 & 10.3 & 8.4 & 6.2 & 5.3 \\
\hline & $\max$. & 11.0 & 12.2 & 11.2 & 11.1 & 11.0 \\
\hline \multirow{3}{*}{ Total P $(\mu \mathrm{g} / 1)$} & $\min$. & 9 & 10 & 11 & 12 & 11 \\
\hline & mean & 13.7 & 15.8 & 19.1 & 18.9 & 35.2 \\
\hline & $\max$. & 20 & 22 & 28 & 25 & 125 \\
\hline \multirow{3}{*}{$\mathrm{P}-\mathrm{PO} 4(\mu \mathrm{g} / \mathrm{l})$} & $\min$. & 3.0 & 2.0 & 4.0 & 4.1 & 4.0 \\
\hline & mean & 6.7 & 5.6 & 6.4 & 7.1 & 19.4 \\
\hline & $\max$. & 10.0 & 9.0 & 11.0 & 13.1 & 66.0 \\
\hline \multirow{3}{*}{$\mathrm{N}-\mathrm{NO} 3(\mu \mathrm{g} / 1)$} & $\min$. & 2.0 & 2.0 & 4.0 & 4.0 & 6.0 \\
\hline & mean & 6.9 & 7.6 & 8.6 & 13.7 & 28.4 \\
\hline & $\max$. & 14.0 & 12.0 & 17.0 & 38.0 & 77.0 \\
\hline \multirow{3}{*}{$\mathrm{N}-\mathrm{NO} 2(\mu \mathrm{g} / \mathrm{l})$} & mir & 0.1 & 0.1 & 0.0 & 0.1 & 0.0 \\
\hline & mean & 0.4 & 0.3 & 0.4 & 0.7 & 2.1 \\
\hline & $\max$. & 0.8 & 0.8 & 1.0 & 1.8 & 14.0 \\
\hline \multirow{3}{*}{$\mathrm{N}-\mathrm{NH} 3(\mu \mathrm{g} / 1)$} & $\min$. & 1.0 & 2.0 & 2.0 & 3.0 & 1.0 \\
\hline & mean & 3.4 & 3.5 & 4.8 & 13.5 & 61.6 \\
\hline & $\max$ & 6.0 & 6.0 & 14.0 & 36.0 & 243.0 \\
\hline
\end{tabular}

identified at the genus or species group level. Additional samples were collected for laboratory larval rearing in order to obtain specific adult identification of the most diffused taxa. The oligochaete/chironomid ratio $(\mathrm{O} / \mathrm{O}+\mathrm{C} \%$, Wiederholm 1980) was adopted to point out the trophic status of Lake Vico. The Shannon diversity index (Pielou 1969) was calculated as a synthetic expression of chironomid community structure. Principal Component Analysis (PCA), largely utilized in benthic studies on freshwater ecosystems to evidence environmental gradients (Rae 1985, Bradt \& Berg 1987, Glazier \& Gooch 1987, Allison \& Harvey 1988, Diaz 1989, Reynoldson 1990), was carried out on the $\log (x+$ 1) transformed densities to detect relationships between depths and chironomid assemblages. Linear correlations were made on $\log (x+1)$ (Elliott 1977) or arcsin $\sqrt{\mathrm{P}}$ (Sokal \& Rohlf 1973) transformed absolute and relative data, respectively. Statistical treatments were performed using SPSS/PC software. 


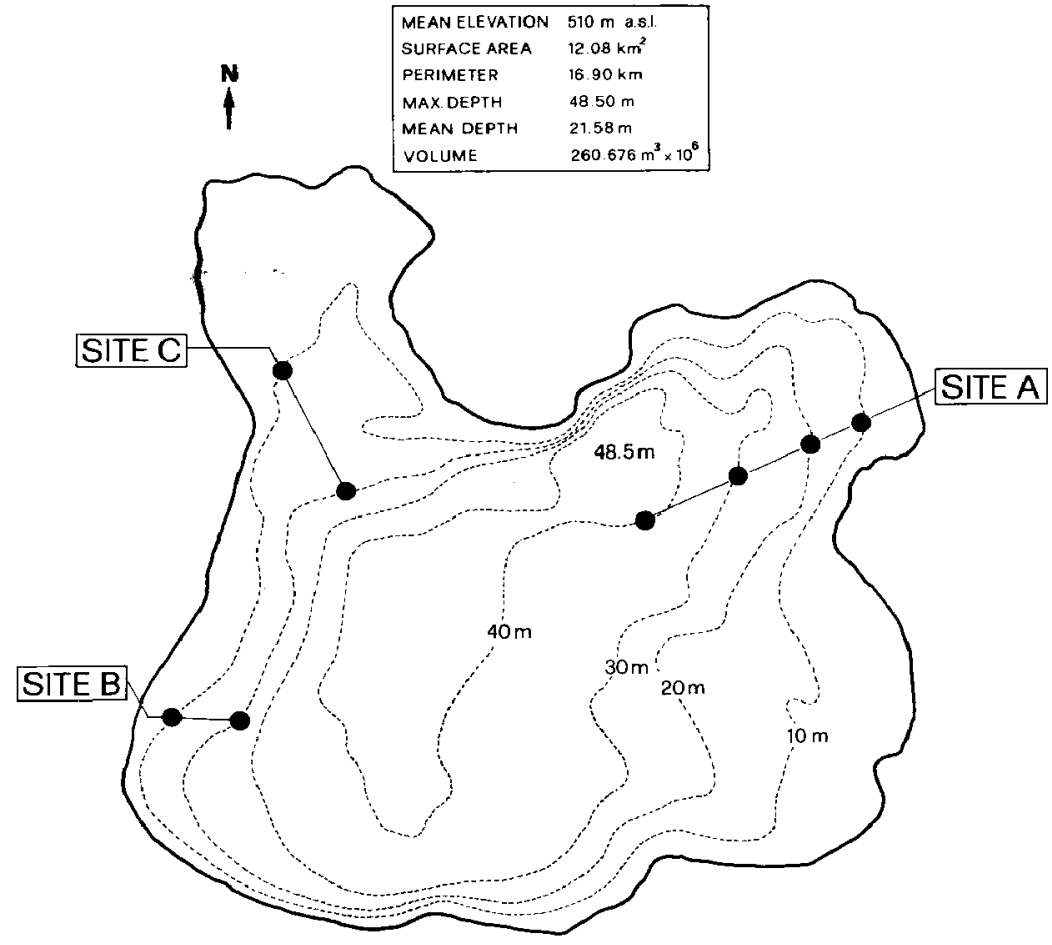

$i \mathrm{~km}$

Fig. I : Morphometric data and sketch map of Lake Vico with sampling sites (A, B and C) and depths (from Barbanti, 1969). 


\section{Results}

About 7000 chironomid larvae and pupae betonging to 15 taxa were collected and identified during the study (Table II). Sublittoral and profundal chironomids of Lake Vico accounted, on average, for $36.04 \%$ of density of the total benthic fauna, with a minimum of $0.3 \%$ and a maximum of $76.0 \%$. The minimum, mean and maximum percentage values on total fauna biomass were $0.2 \%, 36.25 \%$ and $80.6 \%$, respectively. Seasonal values of chironomid densities and biomasses at sampling sites and depths are reported in figure 2 . The extreme values registered were 15 and $12976 \mathrm{ind} / \mathrm{m}^{2}$ for densities, 0.01 and $11.63 \mathrm{~g} / \mathrm{m}^{2}$ for biomasses. In all three sites, the highest densities and biomasses generally occurred at $20 \mathrm{~m}$ depth and the lowest ones at $40 \mathrm{~m}$ depth, whereas intermediate values were recorded at 10 and $30 \mathrm{~m}$ depths. Both density and biomass decreased with increasing depth $(\mathrm{r}=-0.53, \mathrm{p}<0.001$ and $r=-0.43, p<0.01$, respectively). The number of taxa showed the highest values at $10 \mathrm{~m}$ and the lowest at $40 \mathrm{~m}$, significantly decreasing with depth $(r=-0.74, p<0.001)$. Diversity ranged from 0 , sometimes recorded at 30 and $40 \mathrm{~m}$, to 2.54 occurring at $10 \mathrm{~m}$ (Table II), and was inversely correlated to the depth $(r=-0.70, p<0.001)$. The most frequent and abundant genera (Table 11 and Fig. 3) were Procladius, Tanytarsus and Micropsectra, followed by Paratendipes and Microtendipes. The remaining taxa were less frequent and/or present in low numbers and percentages. Polypedilum nubeculosum gr., P. bicrenatum gr., Parachironomus, Chironomus sp. and Pentaneurini were present only in $10 \mathrm{~m}$ samples (Table II).

The oligochaete/chironomid ratio (Table II) generally showed annual mean values from $44.3 \%$ to $82.4 \%$ at 10 and $20 \mathrm{~m}$ depths, and increased at 30 and $40 \mathrm{~m}$, where the theoretical maximum was reached at the end of the thermal stratification. The values of this index significantly increased with increasing depth $(r=0.46, p<0.001)$. An inverse correlation ( $\mathrm{r}=-0.57, \mathrm{p}<0.001)$ was found between chironomid diversity and oligochaete/chironomid ratio.

The statistical comparisons performed on several parameters of the community structure (i.e. density of taxa, percentages, diversity, total density and biomass, etc.) by means of the non-parametric Wilcoxon test (Eason et al. 1980) did not suggest any clear pattern in the chironomid spatial distribution and seasonal variation among the three sites, so that such aspects are not considered.

The PCA analysis (Fig. 4, Table III) was performed on a set of 48 data ( 8 depth stations per 6 sampling visits). Taxa occur ring with percentages lower than $1 \%$ of the total chironomid fauna were not considered (taxa $1,2,12,15$ in Table II). The first two principal components accounted for $53.5 \%$ of the total variance. The second factor separates most of the $10 \mathrm{~m}$ stations from those situated in the deepest area of the lake. The latter stations are ordered along factor 1 according to a gradient of depth. In fact, excluding $10 \mathrm{~m}$ stations from the previous pool of data, there is a highly significant correlation $(r=0.89, \mathrm{p}<0.001)$ between depth and distances of the remaining sampling stations from factor 2 .

Table III : Factor loadings of chironomid taxa from Lake Vico. Values lower than $|0.50|$ were arbitrarily neglected.

\begin{tabular}{|c|c|c|}
\hline Factors & $\begin{array}{c}\text { Principal } \\
1\end{array}$ & $\begin{array}{c}\text { Components } \\
2\end{array}$ \\
\hline Eigenvalue & 3.98 & 1.90 \\
\hline Variance accounted for $(\% / 0)$ & 36.2 & 17.3 \\
\hline \multicolumn{3}{|l|}{ Variables } \\
\hline Micropsectra & 0.85 & \\
\hline Procladius & 0.81 & \\
\hline Microtendipes & 0.73 & \\
\hline Tanytarsus & 0.72 & \\
\hline Paratendipes & 8.51 & \\
\hline Cryptochironomus & & 0.85 \\
\hline Polypedilum bicrenatum gr. & & 0.76 \\
\hline Cladopelma Jateralis gr. & & 0.57 \\
\hline C. laccophila gr. & & 0.55 \\
\hline
\end{tabular}

\section{Discussion}

Chironomids of Lake Vico were essentially characterized by densities and biomasses strongly infuenced by increasing depth. Diversity values indicated a more diversified community at 10 and $20 \mathrm{~m}$, whereas a more simplified and monotonous structure was generally present at 30 and $40 \mathrm{~m}$, especially during the stratification period when the oxygen deficit comes into effect.

A clear picture of the depth distribution of chironomids is provided by the plot of the sampling stations derived from the PCA analysis. It describes 
Table II : Mean and range of density, number of taxa, diversity and oligochaete/chironomid ratio of sublittoral and profundal chironomids at the sampling sites and depths in Lake Vico. Procladius choreus (Meigen), Cladopelma virescens (Meigen), Microtendipes cf. pedellus (DeGeer) and Paratendipes albimanus (Meigen) resulted from the adult identification.

\begin{tabular}{|c|c|c|c|c|c|c|c|c|c|}
\hline \multirow{2}{*}{$\begin{array}{l}\text { Fites } \\
\text { lepth (n) }\end{array}$} & & \multicolumn{4}{|c|}{ A } & \multicolumn{2}{|c|}{ B } & \multicolumn{2}{|c|}{6} \\
\hline & & 10 & 20 & 50 & 10 & 10 & 20 & 10 & 20 \\
\hline \multirow{3}{*}{ 1. Psectrocledifus } & nin. & 0 & 0 & 0 & 0 & 0 & 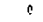 & $"$ & 0 \\
\hline & ut an & $\mathbf{J}$ & 3 & 0 & 0 & $\theta$ & $\theta$ & 10 & 0 \\
\hline & $\omega x$ & 15 & 15 & 0 & 0 & 0 & 0 & 4 & 0 \\
\hline \multirow{3}{*}{ 2. Fentaneuring } & ain. & 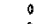 & 0 & 0 & 0 & 0 & 0 & 0 & 0 \\
\hline & Bean & 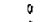 & 0 & 0 & 0 & 5 & 0 & 0 & J \\
\hline & ask. & 0 & 0 & 0 & 0 & 15 & 0 & 0 & 0 \\
\hline \multirow{3}{*}{ 3. Froclsetus } & $=1 n$ & $11^{9}$ & 174 & 59 & $i^{*}$ & 30 & 100 & 192 & 222 \\
\hline & Mean & $u 3$ & 1011 & 417 & 15 & 790 & 958 & 675 & 1458 \\
\hline & ABX. & $222 ?$ & $1.64 \%$ & $\mathrm{i} i \mathrm{i} \mathrm{y}$ & 118 & 2074 & 1607 & 1200 & ij65 \\
\hline \multirow{3}{*}{ 4. Tanytarsus } & in. & 0 & 267 & 0 & 0 & 15 & 71 & 15 & 548 \\
\hline & Teat & 264 & 1578 & 67 & 50 & 296 & 360 & $6: 5$ & S13 \\
\hline & $\omega x$ & 548 & 3481 & 753 & 19 & $136]$ & $\$+4$ & 1615 & 1172 \\
\hline \multirow{3}{*}{ 5. Micropsetera } & nin. & 0 & 201 & 0 & 0 & 0 & 30 & 0 & 14 \\
\hline & משת & 27 & 900 & 210 & 32 & 25 & 201 & 33 & 1743 \\
\hline & tax. & 69 & 2074 & 563 & 119 & 103 & 607 & 103 & 7549 \\
\hline \multirow{3}{*}{ 6. tladgpelod larcoghila gr. } & min. & 0 & 0 & 0 & 0 & D) & 0 & 0 & 0 \\
\hline & vedn & 64 & 25 & 3 & 9 & 67 & 5 & 35 & 12 \\
\hline & $\operatorname{sax}$ & 110 & 119 & 15 & 0 & 341 & 15 & 89 & 4 \\
\hline \multirow{3}{*}{ 7. } & nin. & n & 0 & 0 & 0 & 0 & 0 & 0 & 0 \\
\hline & nean & 106 & 30 & s & 0 & 101 & 36 & 17 & $\mathbf{j}$ \\
\hline & ax. & 535 & 74 & 15 & 0 & 489 & 124 & 133 & IS \\
\hline \multirow{3}{*}{ 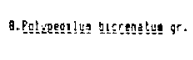 } & $\sin$. & 0 & 0 & 0 & $\theta$ & 0 & 0 & $D$ & 0 \\
\hline & Meán & 20 & 0 & $a$ & 0 & 17 & 0 & 5 & 0 \\
\hline & nax. & 24 & 0 & 0 & 0 & 74 & 0 & $3 n$ & 2 \\
\hline \multirow{3}{*}{ 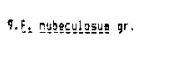 } & sin. & 0 & 0 & 0 & 0 & 0 & 0 & ! & 0 \\
\hline & nean & 3 & 0 & 0 & 0 & 5 & 0 & 1) & $\theta$ \\
\hline & $\operatorname{six}$ & 133 & 0 & 0 & 0 & 30 & ? & 8 & 0 \\
\hline \multirow{3}{*}{ 10. Mictotenfirgs } & in. & 0 & 59 & 0 & 0 & 0 & 0 & 0 & 0 \\
\hline & asan & $! 2 !$ & 100 & 52 & 3 & 5 & 19 & 51 & 52 \\
\hline & max. & 781 & 1249 & 101 & 15 & 30 & 89 & 222 & 140 \\
\hline \multirow{3}{*}{ 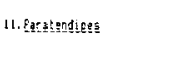 } & ain. & 15 & 0 & 0 & 0 & 0 & 15 & 15 & 15 \\
\hline & טegn & 193 & 64 & 10 & 0 & 72 & 274 & 351 & $3 I$ \\
\hline & A. & 519 & 133 & 59 & 0 & 296 & 795 & $100 ?$ & 74 \\
\hline \multirow{3}{*}{ 12. Farachirougnus } & ain. & 0 & 0 & 0 & 0 & 0 & 0 & ") & 9 \\
\hline & sean & 3 & 0 & 0 & 0 & 0 & 0 & 3 & 0 \\
\hline & ads. & 15 & 0 & 0 & $\theta$ & 0 & 0 & 15 & 0 \\
\hline & ain. & 0 & 0 & 0 & 0 & 0 & 0 & 0 & 0 \\
\hline 13. Cregtochirgnogus & vean & 30 & 15 & 0 & 0 & 8 & 3 & 70 & 0 \\
\hline & $\cos x_{1}$ & 103 & 11 & 0 & 0 & 30 & 15 & 207 & 0 \\
\hline & - in. & 0 & 0 & 0 & 0 & 0 & 0 & 0 & 0 \\
\hline 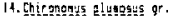 & Eean & 358 & 22 & so & 0 & 25 & 72 & 30 & 17 \\
\hline & ax. & $n 1$ & 59 & 30 & 0 & 74 & 163 & 59 & 44 \\
\hline & sin. & 0 & 0 & 0 & 0 & 0 & 0 & 0 & 0 \\
\hline 15. Chirongens 37. & ean & 7 & 0 & 0 & 0 & 0 & 0 & 0 & 0 \\
\hline & Ads. & 14 & 0 & 0 & 0 & 0 & 0 & 0 & 0 \\
\hline & sin. & 4 & 6 & I & 1 & 3 & 6 & 6 & 4 \\
\hline Nubbet of taed & rean & 9 & 8 & 1 & 2 & 1 & 7 & B & $\Delta$ \\
\hline & ax. & II & $\uparrow$ & 5 & 3 & 9 & 8 & $1^{n}$ & E \\
\hline & min. & 1.32 & 1.29 & 0.00 & 0.09 & 1.30 & 1.31 & $1.1 t$ & 6.94 \\
\hline giver sity & Mean & 2.17 & 1.79 & 1.16 & 0.58 & 1.82 & 1.68 & 1.89 & 1.55 \\
\hline & $a x$ & 2.54 & 2.22 & 1.93 & 1.35 & 2.19 & 2.17 & 2.49 & $1.9 \div$ \\
\hline & wir. & 55.2 & 13.9 & 50.0 & 31.1 & 11.7 & 71.3 & 37.0 & bit \\
\hline 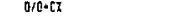 & moan & 31.8 & 4.3 & 92.6 & 93.8 & 82,4 & 79.2 & 57.1 & 65.6 \\
\hline & Bax. & 82.5 & 60.2 & 100.0 & 100.0 & 97.5 & 87.2 & 92.8 & 95.7 \\
\hline
\end{tabular}



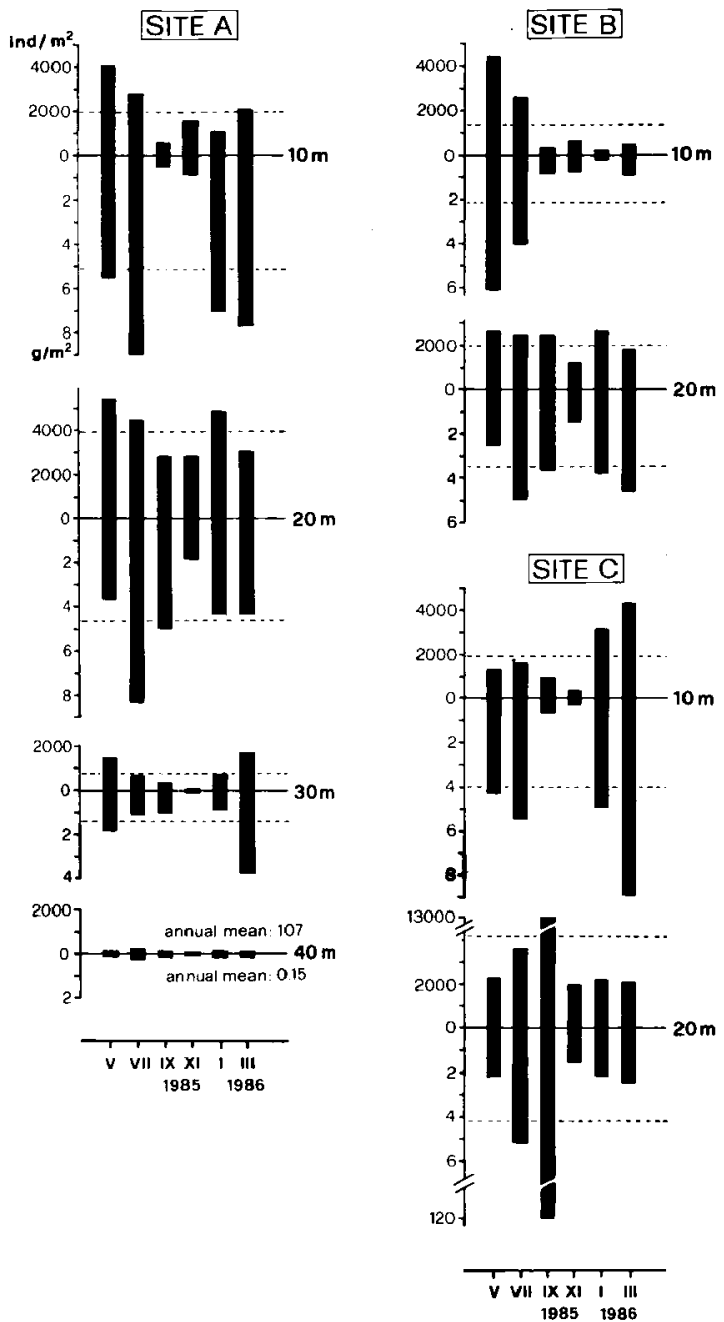

Fig. 2 : Densities (ind $\left./ \mathrm{m}^{2}\right)$ and biomasses $\left(\mathrm{g} / \mathrm{m}^{2}\right)$ of the total chironomids at sites $\mathrm{A}, \mathrm{B}$ and $\mathrm{C}$ and depths. Interrupted lines indicate annual mean values. 

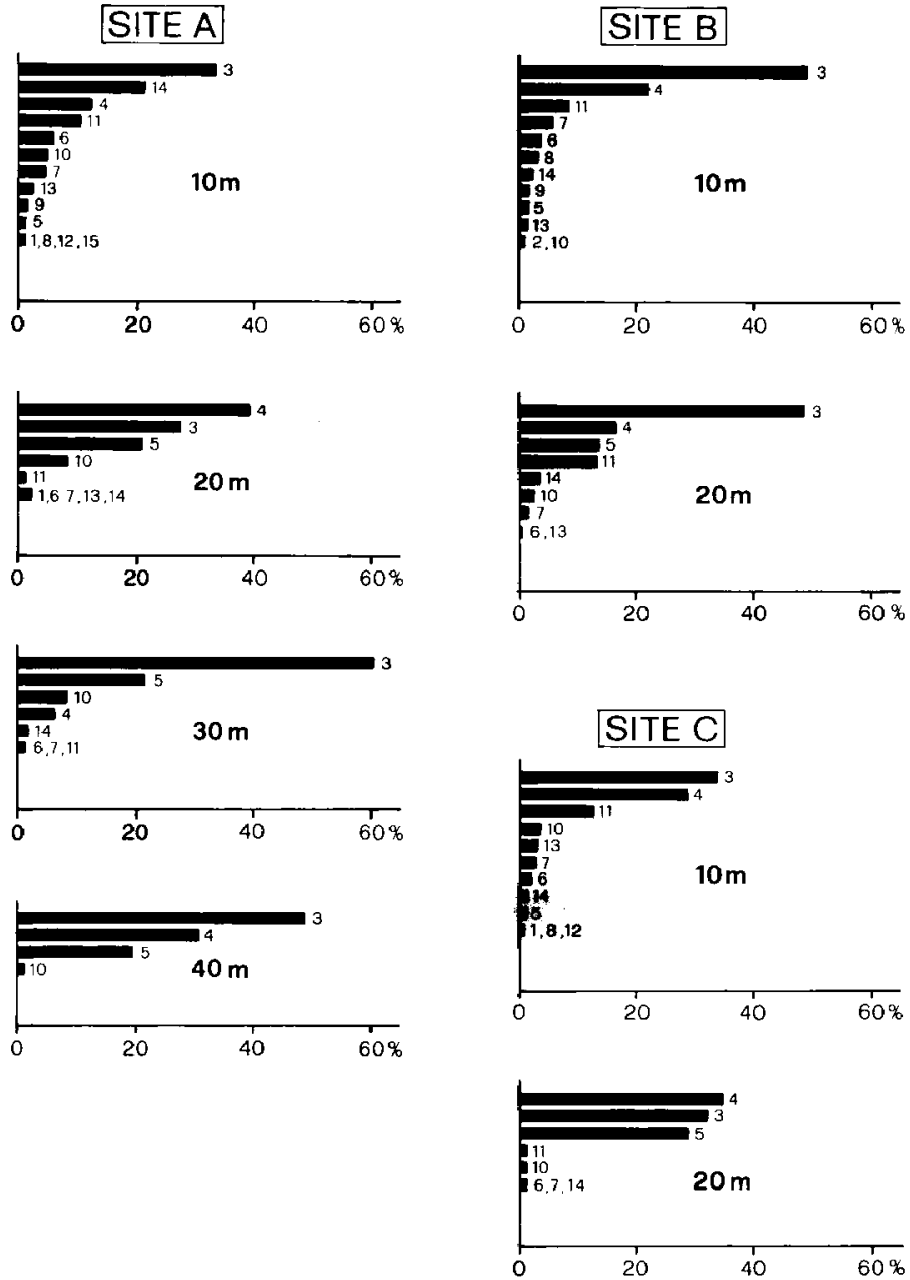

Fig. 3 : Annual mean percentages of taxa on the total chironomids at the sampling sites and depths. Taxa numbered as in Table II. 


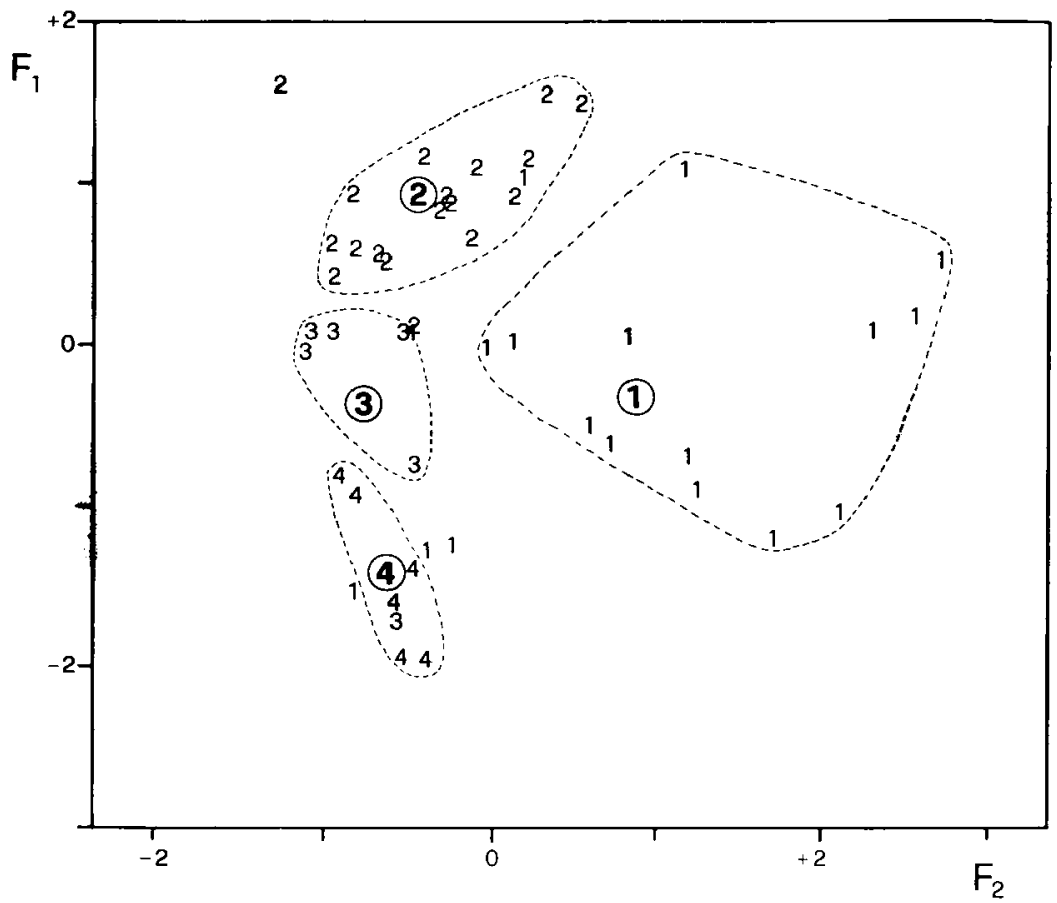

Fig. 4 : Plot of factors 1 and 2 of the PCA analysis. Numbers 1,2,3 and 4 indicate the 10,20,30 and $40 \mathrm{~m}$ depth stations, respectively. Circled numbers represent centroids.

the separation of the sublittoral stations at $10 \mathrm{~m}$ from those at depths of 20,30 and $40 \mathrm{~m}$, which represent the true profundal zone with homogeneous environmental features. The arrangement of 20,30 and $40 \mathrm{~m}$ depths along $\mathrm{Fl}$ indicates that the chironomid structure in Lake Vico (i.e. proportion of the most relevant taxa) substantially remained the same along the depth gradient, changing mainly as a result of a gradual loss of taxa and lowering of absolute densities. Typically profundal chironomids resulted to be Micropsectra, Procladius, Microtendipes, Tanytarsus and Paratendipes. Among them, Microp- sectra appeared more closely linked to the deeper part of the lake (Fig. 3 and Table III). The other genera were well represented at all depths, but they were almost the only taxa present in the profundal of the lake. On the contrary, the higher variability in both occurrence and densities of chironomid taxa among sites and seasons at $10 \mathrm{~m}$ makes these stations more highly dispersed and not comparable with a real profundal biocoenosis. Thus, on this basis the group of $10 \mathrm{~m}$ stations should be ascribed to a distinct sublittoral zone with characterizing elements such as Cryptochironomus, Polypedilum bicre- 
natum gr., Cladopelma lateralis gr. and C. laccophila gr., well represented also in the littoral of the same lake (Mastrantuono \& La Rocca 1988). The distinction between the sublittoral and the profun$\mathrm{dal}$ zone is also supported by the occurrence of taxa exclusively present at $10 \mathrm{~m}$ stations, and of vegetation debris (mainly Characeae) only in the samples from these depths. Other authors (i.e. Laville 1971, Lindegaard 1980, Heinis 1989) already found that chironomid community structure shifts from a littoral to a profundal pattern showing that the intermediate environmental character of the sublittoral zone is often related to changes in substrate type, food availability, oxygen content, water quality, etc. A similar picture has been observed also for lacustrine malacocoenoses (Mouthon 1989), making it apparent that many benthic animals are distributed along a depth-dependent environmental gradient.

Chironomids can also provide useful trophic indications for Lake Vico. Unfortunately, the absence of the required indicator taxa and the lack of specific identifications made it impossible to evaluate the lake trophy level by means of Saether's trophic key (Saether 1979), but the occurrence of good quantities of Tanytarsini should traditionally lead to the assessment of a mesotrophic condition of the profundal sediments (cf. Thienemann 1925 \& 1954 , Brundin 1949 \& 1956). Indeed, especially in recent decades, the specific identification of taxa belonging to this group has been strongly recommended for a better comprehension of the relationship among these taxa and the trophic level of lakes. In fact, i.e. the genus Tanytarsus holds species with very different ecological sensitivity, varying from oligotrophy to slight eutrophy (Reiss \& Fittkau 1971, Saether 1979, Kansanen et al. 1984, Gerstmeier, 1989b). Conversely, a reliable mesotrophy indication is provided by the presence in large abundances of Micropsectra, considered as an oligo-mesotrophic taxon with a narrow trophic range even at the level of genus (Wiederholm 1973 \& 1976, Saether 1979, Wiederholm \& Eriksson 1979, Gerstmeier 1989b). Thus, this taxon can be considered as a key indicator in detecting future trophic changes in Lake Vico. The other common genera were all eurytopic forms living in a wide trophic range, with the exception of the traditionally eutrophic Chironomus plumo. sus gr.

The oligochaete/chironomid ratio seems to confirm the diagnosis of mesotrophy indicated by the previous considerations. In fact, the values registered in Lake Vico are lower than those recorded at the same depths in slightly to strongly eutrophic waters of Central Italy (Bazzanti \& Seminara 1987a \& 1987b, Bazzanti \& Seminara 1988, Seminara \& Bazzanti 1988). Moreover, the inverse trend of this environmental index and of the chironomid diversity with respect to depth is indicative of the suitability of this latter in monitoring ecological changes along a depth gradient, as already observed for entire benthic communities (Bazzanti \& Seminara 1987c, Bazzanti \& Seminara 1988).

In synthesis, according to chemical data, the sublit toral and profundal chironomids of Lake Vico indicated a mesotrophic condition of the waters. However, emphasis should be laid on the tendency towards increasing trophy in the deepest layers of the hypolimnion, as revealed by high values of total $P$, the occurrence of summer-autumn oxygen depletion, reduction of diversity and abundances of chironomid communities, and constantly high values of oligochaete/chironomid ratio.

\section{Acknowledgements}

This research was partly supported by an M.P.I. grant. We wish to thank Dr E. Gelosi for the general organization of the main research on the lake and for permission to publish the chemical data.

\section{References}

Aagaard (K.). 1978. - The chironomids of Lake Mälsjoen. A phenological, diversity, and production study. Norw. J. Ent. 25 : 21-37.

Allison (W.R.) \& Harvey (H.H.). 1988, - Composition, distribution and standing crop of the benthos in a shallow lake. Verh. Internat. Verein. Limnol, $23: 241-245$.

Barbanti (L.). 1969. - Lago di Vico : rilevamento batimet rico e note geomorfologiche. Mem. Ist. Ital. Idrobiol., 25 : 117-139.

Barbanti (L.), Bonomi (G.), Carollo (A.), Chiaudani (G.), Ferrari (I.), Gerletti (M.), Nocentini (A.M.), Ruggiu (D.) \& Tonolli (L.). 1971. - Limnologia ed ecologia dei laghi di Bolsena, Bracciano, Trasimeno e Vico : situazione attuale e prevedibili conseguenze derivanti da una loro utilizzazione multipla. Istituto Italiano di Idrobiologia, Pallanza, $263 \mathrm{p}$.

Bazzanti (M.). 1981. - Survey of the macrobenthic community in an area of Lake Bracciano (Central Italy). Boll. Zool., 48 ; 295-303.

Bazzanti (M.) \& Loret (E.). 1982. - Macrobenthic community structure in a polluted lake : Lake Nemi (Central Italy). Boll. Zool., $49: 79.91$.

Bazzanti (M.) \& Seminara (M.). 1987a. - Profundal macrobenthos structure as a measure of long-term environmental stress in a polluted lake. Water, Air Soil Pollut., 33:435-442. 
Bazzanti (M.) \& Seminara (M.). 1987b. - Environmental stress in a regulated eutrophic lake indicated by the profundal macrobenthic community. Boll. Zool., 54 : 261-266.

Bazzanti (M.) \& Seminara (M.). 1987c. - Profundal macrobenthos in a polluted lake. Depth distribution and its relationship with biological indices for water quality assessment. Acta Oecologica/Oecol. Applic., $8: 15-26$.

Bazzanti (M.) \& Seminara (M.). 1988. - Distribuzione con la profondità della comunità macrobentonica sublitorale e profonda del Lago Albano. LII Congresso Nazionale dell'Unione Zoologica Italiana, Camerino, 12-16 Set tembre 1988.

Bradt (P.T.) \& Berg (M.B.). 1987. - Macrozoobenthos of three Pennsylvania lakes : responses to acidification. Hydrobiologia, $150: 63-74$.

Brundin (L.). 1949. - Chironomiden und andere Bodentiere der Südschweden Urgebirssen. Rep. Inst. Freshwt. Res. Drottningholm, $30: 1-914$.

Brundin (L.). 1958. - The bottom faunistic lake type system and its application to the southern hemisphere. Moreover a theory of glacial erosion as a factor of productivity in lakes and oceans. Verh. Internat. Verein. Limnol., $13: 288-297$.

Diaz (R.J.). 1989. - Pollution and tidal benthic cornmunities of the James River Estuary, Virginia. Hydrobiologia, 180 : 195-211.

Eason (G.), Coles (C.W.) \& Gettinby (G.). 1980. - Mathematics and statistics for the biosciences. Ellis Horwood Ltd., Chichester, $578 \mathrm{p}$.

Elliott (J.M.). 1977. - Some methods for the statistical analysis of samples of benthic inver tebrates. Scient. Publs. Freshwat. Biol. Ass., $25: 1-160$.

Gallepp (G.W.), Kitchell (J.F.) \& Bargell (S.M.). 1978. Phosphorous release from lake sediments as affected by chironomids. Verh. Int. Verein. Limnol, $20: 458-465$.

Gardner (W.S.), Nalepa (T.F.), Slavens (D.R.) \& Laird (G.A.). 1983. - Patterns and rates of nitrogen release by benthic Chironimidae and Oligochaeta. Can. J. Fish. Aquat. Sci., $40: 259-266$.

Gerstmeier (R.), 1989a. - Pherkology and bathymętriç distribution of the profundal chironomid fauna in Starnberger See (F.R. Germany). Hydrobiologia, $184: 29-42$.

Gerstmeier (R.). 1989b. - Lake typology and indicator organisms in application to the profundal chironomid fauna of Starnberger See (Diptera, Chironomidae). Arch. Hydrobiol., $116: 227-234$

Glazier (D.S.) \& Gooch (J.L.). 1987. - Macroinvertebrate assemblages in Pennsylvania (U.S.A.) springs. Hydrobiologia, $150: 33-43$.

Granéli (W.). 1979. - The influence of Chironomus plumosus larvae on the exchange of dissolved substances between sediment and water, Hydrobiologia, 66 : 149-159.

Heinis (F.). 1989 . - The relation between oxygen regimes and distribution patterns of the larvae of Chironomidae. 24th Congress of the Societatis Internationalis Limnologiae (abstract).

Heinis (F.), Van De Bund (W.J.) \& Davids (C.). 1989. Avoidance of low oxygen and food concentrations by the larvae of Tanytarsus sp.. Acta Biol. Debr. Oecol. Hung., 3 : 141-145.

Kansanen (P.H.), Aho (J.) \& Paasivirta (L.). 1984. - Testing the benthic lake type concept based on chironomid associations in some Finnish lakes using multivariate statistical methods. Ann. Zool. Fennici, 21 : 55-76.
Laville (H.) . 1971. - Recherches sur les Chironomides (Diptera) lacustres du Massif de Néouvielle (Hautes Pyrénées). 2. Communauté et production. Annls. Limnol, 7 : 335-414.

Lindegaard (C.). 1980 - Bathymetric distribution of Chironomidae (Diplera) in the oligotrophic Lake Thingvallavatn, Iceland. In :Chironomidae. Ecology, Systematics, Cytology and Physiology. D.A. Murray, ed., Pergamon Press. Oxford and New York, p. 217-224.

Mastrantuono (L.). 1986. - Littoral sand zoobenthos and its relation to organic pollution in Lake Nemi (Central Italy). Hydrobiol. Bull. $19: 171-178$.

Mastrantuono (L.). 1987. - Invertebrate community in the littoral-regulated area of a hydroelectric lake-reservoir (Lake Campotosto, Central Italy). Riv. Idrobiol, $26: 17-32$.

Mastrantuono (L.) \& La Rocca (C.). 1988. - The invertebrate fauna in sandy shores of Lake Vico (Italy) : its use in a trophic evaluation of littoral sediments. Ecologia Mediterranea, $14: 121-129$.

Mouthon (J.). 1989. - Analyse de la distribution des malacocénoses de 23 lacs français. Annls Limnol, $25: 205-213$.

Nicotra (G.). 1987. - Studio sulle caratteristiche chimico-fisiche del Lago di Vico. Osservazioni su un ciclo di ricerche condoule mensilmente durante il periodo maggio 1985 - maggio 1986. Unpubl. Report, Stabilimento Ittiogenico - Roma, Regione Lazio, 46 p.

Nocentini (A.M.). 1973. - La fauna macrobentonica litorale e sublitorale dei laghi di Bolsena, Bracciano e Vico (Italia Centrale, Lazio). Mem. Ist. Ital. Idrobiol., $30: 97-148$.

Pielou (E.C.). 1969. - An introduction to mathematical ecology. J. Wiley, New York, $286 \mathrm{p}$.

Pinder (L.C.V.) \& Reiss (F.). 1983. - The larvae of Chironominae (Diptera : Chironomidae) of the Holarctic region. Key and diagnoses. In : Chironomidae of the Holarctic region. Key and diagroses. Part. 1. Larvae. T. Wiederholm, ed., Enl. Scond. Suppl., $19: 293-447$.

Rae (J.G.). 1985. - A multivariate study of resource partitioning in soft bottom lotic Chironomidae. Hydrobiologia, 126 : 275-285.

Reiss (F.) \& Fittkau (E.J.). 1971. - Taxonomie und Okologie europäisch verbreiteter Tanytarsus-Arten (Chironomidae, Diptera). Arch. Hydrobiol. Suppl., 40: 75-200.

Reynoldson (T.B.). 1990. - Distribution patterns of oligochaetes in the English Lake District. Arch. Hydrobiol, 118 : 303-339.

Saether (O.A.). 1979. - Chironomid communities as water quality indicators. Holarct. Ecol, 2 : 65-74.

Seminara (M.) \& Bazzanti (M.). 1988. - Trophic level assessment of profundal sediments of the artificial Lake Campotosto (Central Italy), using midge larval community (Diptera : Chironomidae). Hydrobiol. Bull., 22 : 183-193.

Sokat (R.R.) \& Rohlf (J.R.). 1973. - Introduction to biostaistics. W.H. Freeman and Co., San Francisco, 368 p.

Thienemann (A.). 1925. - Die Binnengewässer Mitteleuropas. Eine Limnologische Einfuhrung. Binnengewässer, 1: 1-255.

Thienemann (A.). 1954. - Chironomus. Leben, Verbreitung und wirtschaftliche Bedeutung der Chironomiden. Binnengewässer, $20: 1-834$.

Warwick (W.F.). 1980. - Chironomidae (Diptera) responses to 2800 years of cultural influence : a palaeolimnological study with special reference to sedimentation, eutrophication and contamination processes. Can. Ent., $112: 1193-1238$. 
Wassen (J.G.). 1984. - L'utilisation des peuplements larvaires de Chironomidae (Diptera) pour la diagnose écologique des lacs: essai d'application aux deux lacs de Clairvaux (Jura, France). Revue Sciences de l'eau, $3: 395-408$.

Wiederholm (T.). 1973. - Bottom fauna as an indicator of water quality in Sweden's large lakes. Ambio, 2 : 107-110.

Wiederholm (T.). 1976. - Chironomids as indicators of water qualtity in Swedish lakes. Naturvärdsverkets Limnologiska Undersökning. NLU Information 10, $17 \mathrm{p}$.
Wiederholm (T.). I980. - Use of bent hos in lake monitoring, J. Wat. Pollut. Cont. Fed., $52: 537,547$.

Wiederholm (T.) \& Eriksson (L.). 1979. - Subfossil chironomids as evidence of eutrophication in Ekoln Bay, Central Sweden. Hydrobiologia, 62: 195-208. 